\title{
The Response of Coniferous Trees to Industrial Pollution in North- Western Russia
}

\author{
T.A. Sazonova ${ }^{*}, 1$ and A.V. Olchev ${ }^{2}$ \\ ${ }^{I}$ Forest Research Institute, Karelian Research Centre of RAS, 11 Pushkinskaya St., 185910 Petrozavodsk, Russia \\ ${ }^{2}$ Severtsov Institutes of Ecology and Evolution of RAS, 33 Leninsky Prospekt, Moscow, Russia
}

\begin{abstract}
The response of two dominant coniferous species (Picea obovata Ledeb. and Pinus sylvestris L.) of eastEuropean taiga to industrial pollution in the impact zone of the Severonickel metallurgical combine (Murmansk Region, Kola Peninsula) was investigated. The water deficit of the needles and shoots described by shoot water potential $(\Psi)$ was used as indicator of the pollution level in the area. The vitality status of the trees was assessed by visual traits (crown shape, life span and degree of needle damage). It was shown that industrial pollution results in injuring the spruce and pine trees, damaging their conducting system and increasing the water deficit of the needles. Correlation between the visually determined health status of the trees (including needle yellowing and die-back) and their water deficit was higher for spruce than for pine trees. High sensitivity of spruce trees to air pollution may be used in forest ecology for e.g. remote detecting the forest areas with high levels of industrial pollution.
\end{abstract}

Keywords: Pinus sylvestris L., Picea obovata Lebed., water potential, vitality category, industrial pollution.

\section{INTRODUCTION}

The response of natural ecosystems to industrial pollution can be usually detected from satellite images only when ecosystem degradation had already become visible [1]. At the same time, field studies in the polluted areas allow to detect the changes and disturbances of ecosystem functioning in earlier stages and to determine the stability and sign of these changes over time [2-10]. The industrial pollution of forest communities results in strong differentiation of woody plants by the vitality status. It is usually determined by visual traits (crown shape, life span and degree of needle damage) [7,11]. The differentiation is also manifested in changes of different functional parameters of the plants too $[9,12-14]$. Plant water uptake is one of the most informative parameters reflecting plant vital activity, because of its strong dependence on environmental conditions and plant properties [15]. The leaf water potential is also a very universal parameter determining the water status of plants. It is both an indirect descriptor of the water deficit in the plants and the driving force for plant water uptake (e.g. [16]).

The relationships between the vitality categories determined by visual criteria and by functional parameters are substantial for the investigation of morpho-physiological response of tree species on industrial pollution. It is interesting to analyze these relationships for different tree species as a function of various climatic and environmental conditions. Furthermore, mechanisms of diverse resistance level both within one plant community and among different plant species are still not fully investigated $[9,14]$.

\footnotetext{
*Address correspondence to this author at the Institute of Forestry of Karelian Branch of RAS, Petrozavodsk, Russia; Tel: +7-960-2124832;

E-mails: alt86@rambler.ru, aoltche@gmail.com
}

The main goal of this study is to analyze the morphophysiological response of Siberian spruce (Picea obovata Lebed.) and Scots pine (Pinus sylvestris L.) trees of different vitality status to industrial pollution of the Severonickel metallurgical combine.

\section{MATERIAL AND METHODS}

The field observations were carried out in impact zone of the Severonickel metallurgical combine (Murmansk Region, Kola Peninsula) in July-August of 1992-93. The main components of the combine emissions are $\mathrm{SO}_{2}$ and heavy metals $[3,7,8]$. Annual sulphur deposition in the area is 1000-2000 kg km ${ }^{-2}$ год $^{-1}$, heavy metals deposition - 50-500 $\mathrm{kg} \mathrm{km}^{-2}$ год $^{-1}$, and mean $\mathrm{SO}_{2}$ concentration in the air -0.04 $\mathrm{mg} \mathrm{m}^{-3}$ [17]. Experimental plots selected for the study are located about $30 \mathrm{~km}$ away from the combine and represented by forest stands with different stages of tree degradation.

Two dominant tree species of east-European taiga were considered is the study: 100-120-year-old Siberian spruce (Picea obovata Lebed.) and 60-80-year-old Scots pine (Pinus sylvestris L.). All trees in the sample plots were visually divided into four vitality categories [11].

- $\quad$ Category I - healthy trees. Tree crowns have dense foliage without visible damages. Needle life span is 6-9-year that is typical for the region. Dry, second order branches are concentrated in lower part of crown only.

- Category II - slightly impaired trees. Crown is thinned by about $40-45 \%$ because of underdevelopment, damage, early lost of needles, as well as reduced shoot increment. Mean life span of needles is on 1-2 years shorter than for healthy trees. Some part of the needles is damaged by yellowing and necrosis. Die-back of second-order branches is 
observed not only in lower part of crown, but also in its middle part.

- $\quad$ Category III - heavily impaired trees. About $75-80 \%$ of crown is thinned because of pollution damage. There are die-back and drop of a half of shoots of different branching orders. Life span of needles doesn't exceed 3 years.

- $\quad$ Category IV - declining trees. Crowns are ruined and over $90 \%$ thinned. Needle life span is within 1-3 years. $30 \%$ of tree branches have current year needles only. The color of needles is strongly altered.

The sample set for each tree vitality category included 10 trees. Three needled shoots were taken from the middle part of tree crown of each sample tree for measurements of the shoot water potential.

The measurements were continuously carried out during the summer months of 1992-93 and covered the periods with different weather and soil moisture conditions.

The water potentials of the shoots $(\Psi)$ were determined using a pressure chamber $[18,19]$. The measurements were accompanied by measurements of air temperature and relative humidity.

To study the relationship between the shoot's $\Psi$ and needle age, branches or second-order shoots were placed into polyethylene bags [20]. The essence of the method is that the branches isolated from the ambience by the bag are enable to transpire and act as tensiometers, i.e. $\Psi$ of the shoots inside the bag are reached equilibrium with $\Psi$ of the xylem in the branch attachment point. Experiments were provided for 3 pine trees of vital categories I, III and IV. Several branches were taken from each tree, needles were detached from their shoots, and only needles of one age $(1,2,3$, etc. years) were left on the shoot. The shoot with needles was placed in a polyethylene bag and left there for one full day. After that the shoot was cut off and $\Psi$ was determined.

The area of the conducting xylem of the trunk was determined by impregnating the xylem with a die. The tree was cut down and placed into a water-filled vessel; a trunk section $15-20 \mathrm{~cm}$ from the root collar was sawn off under the water; the butt of the tree was kept in the water for one hour, and then rapidly dipped into a vessel with dye solution.
Analysis of experimental data was provided using methods of dispersion, regression and cluster analysis.

\section{RESULTS}

Our field studies showed that spruce and pine trees of vitality category I have 5-8 and even more year-old needles. It is typical for Northern taiga trees. The deterioration of tree vitality status resulted in decrease of lifespan of needles up to 1-2 years (trees of vitality category IV).

Analysis of experimental data showed that $\Psi$ tends to decrease with increase of needle age and decline of tree vitality status (Table 1). Thus, $\Psi$ of 1 year-old needles of pine trees of vital category I ( $\Psi=-0.58 \mathrm{MPa})$ was higher than $\Psi$ of the needles of the same ages of the pines of categories III and IV ( $\Psi=-0.61$ and $-0.63 \mathrm{MPa}$, respectively). The same pattern was observed for 2 and 3 year old needles. Needle age related differences grow with decrease of the tree vitality status (e.g. for young needles of categories I and IV trees, $\Psi$ was higher than that for older ones: on $9 \%$ and $16 \%$, respectively). Hence, the needle water deficit grows with increase of needle age and deterioration of tree vitality status, which finally leads to the drying and die-back of needles.

Table 1. Water Potentials of Pine Shoots with Needles of Different Age, MPa

\begin{tabular}{|c|c|c|c|}
\hline \multirow{2}{*}{ Needle Age, Years } & \multicolumn{3}{|c|}{ Vitality Category } \\
\cline { 2 - 4 } & I & III & IV \\
\hline \hline 1 & $-0.58 \pm 0.19$ & $-0.61 \pm 0.29$ & $-0.63 \pm 0.21$ \\
\hline 2 & $-0.59 \pm 0.16$ & $-0.73 \pm 0.19$ & $-0.75 \pm 0.15$ \\
\hline 3 & $-0.62 \pm 0.16$ & $-0.72 \pm 0.18$ & - \\
\hline 4 & $-0.61 \pm 0.29$ & - & - \\
\hline
\end{tabular}

Changes in needle weight were accompanied by changes in the area of sapwood (Fig. 1). It was shown that the pine trees of category I had 17 living whorls and 17 annual rings in the xylem conducted water throughout the circumference. The trees of III category had 17 living whorls, 13 annual rings conducted water all around (4 ones conducted only partially). The trees of category IV had 12 living whorls, but (a)

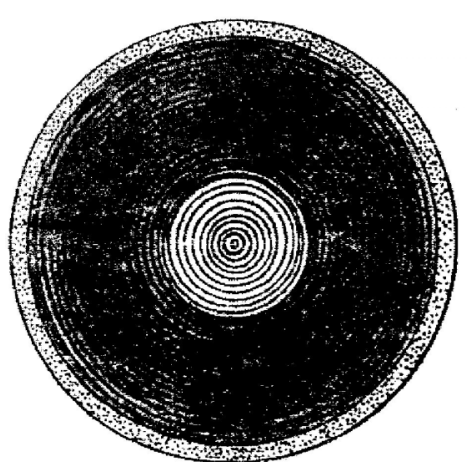

(b)

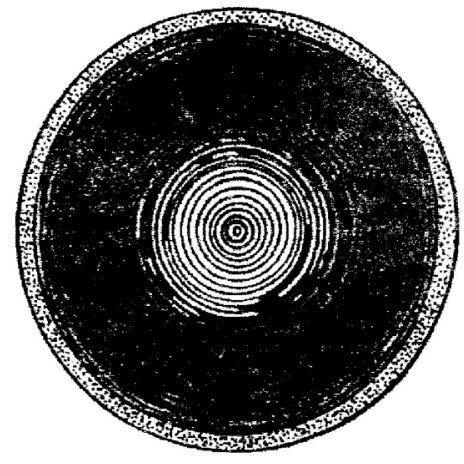

(c)

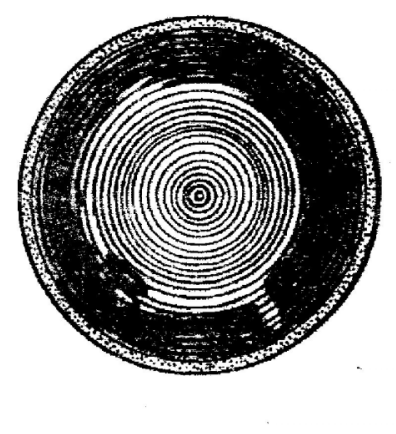

Fig. (1). Sapwood width of pine trees (48 - 53 yrs.) growing under different pollution levels: a - vitality category I, b - category III, $\mathbf{c}-$ category IV. 
only 5 annual rings participated in water transport fully, and 4 - partially. Hence, the area of conducting xylem decreases with deterioration of the tree vitality status, and it may lead to disturbance of the water transport system.

Time, h

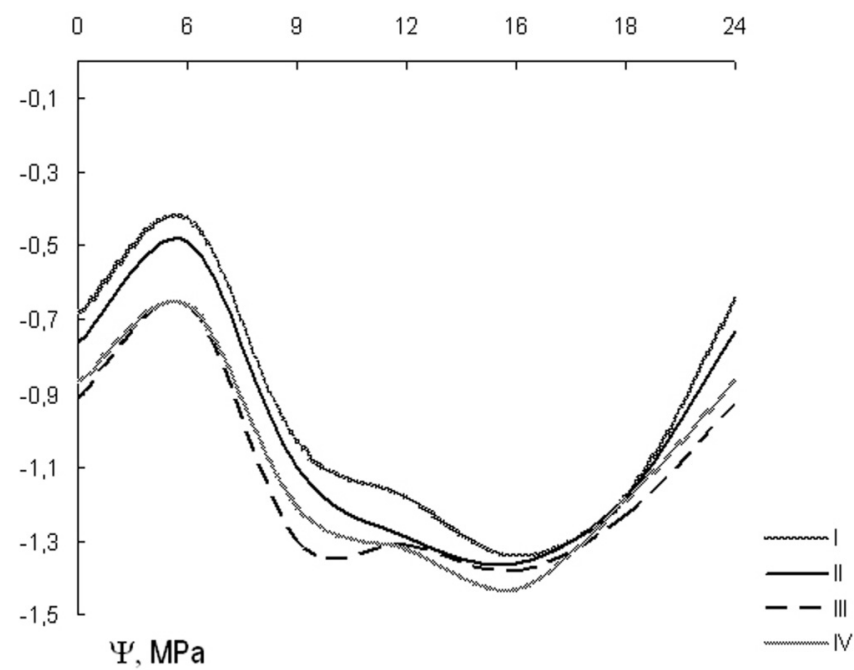

Fig. (2). Daily fluctuations of the water potential ( $\Psi, \mathrm{MPa})$ of needled shoots of spruce trees of different vitality categories (I IV) on 10 July 1993.

Table 2 and Fig. (2) show daily dynamics of $\Psi$ of pine and spruce trees under different weather conditions. The daily patterns of $\Psi$ for spruce and pine trees of different vitality status were quite similar (Fig. 2) [21, 22]. However, in the morning and evening hours the rapid changes of incoming PAR intensity, air temperature and relative humidity resulted in reliable differences in $\Psi$ values for trees of the different vitality status. For example, comparison of $\Psi$ of pine and spruce trees on 4 and 10 July revealed significant differences in $\Psi$ in morning and evening hours. Measurements of $\Psi$ for spruce trees at 12, 16 and 18 o'clock and for pine trees at 13 o'clock revealed no differences related to tree vitality status. Significant differences in $\Psi$ values of the tree of different vitality status were also observed under sharply changing weather conditions (e.g. strong shower after very hot weather).

The relationship between $\Psi$ and the tree vitality status was non-linear. The water deficit in pine and spruce trees increased ( $\Psi$ decreased) from tree category I to III, and either somewhat decreased ( $\Psi$ increased) or even not changed to category IV. Correlation between $\Psi$ and the tree vitality status was higher for spruce than for pine trees (Table 2).

The relationship between $\Psi$ and the tree vitality status was investigated also by cluster analysis. For the analysis thedata on $\Psi$ for pine and spruce trees of category I-IV measured in different time and under different weather conditions were used. All measured pine and spruce trees were grouped into 3 clusters (Fig. 3). Each cluster contains trees of different categories, and their distribution was differed for pine and spruce trees. Thus, the first cluster included the spruce trees of categories I (54\%) and II (46\%), as well as pine trees of all categories (I - 39, II - 22, III - 22 and IV - 17\%). The second cluster included mostly spruce trees of categories III (50\%), IV (38\%) and a little of II $(12 \%)$, as well as pines of all categories (I -12, II - 13, III 37 , IV - 38\%). Finally, the third cluster was represented by two categories of spruce trees - III (43\%) and IV (57\%), and by three categories of pine trees - I (16\%), II (67\%) and IV $(17 \%)$.

These results show that spruce is characterized by a stronger correlation between the vitality status and the water deficit value. Thus, the first cluster, which corresponded to more "favorable" water regime, included healthy and slightly impaired spruce trees (categories I-II). The second "transitional" cluster gathered all categories except category I, and, finally, the third cluster, representing the "unfavorable" water regime, was represented by damaged spruces (categories III-IV). For pine, on the contrary, there was no agreement between observed vitality categories and shoot water potential. Thus, the first ("favourable") and second ("transitional") clusters comprised pine trees of all categories, whereas the third one ("unfavourable"), on the contrary included visually healthy trees of categories I (16\%), II $(67 \%)$, and only $17 \%$ of heavily damaged trees (IV).

These distinctions between the species are evident not only from the ratio of vitality categories within a cluster, but also from the distribution of each category among clusters (Fig. 4). Thus all $(100 \%)$ spruce trees of category I are referred to the first cluster, whereas pine trees of the same category are distributed among the first $(70 \%)$, second $(20 \%)$ and third $(10 \%)$ clusters. Most spruce trees of category II are related to the first cluster $(86 \%)$ and only some part of them $(14 \%)$ - to the second one. The pine trees of category II were similarly distributed among all clusters (I-III) - 40, 20 and $40 \%$, respectively.

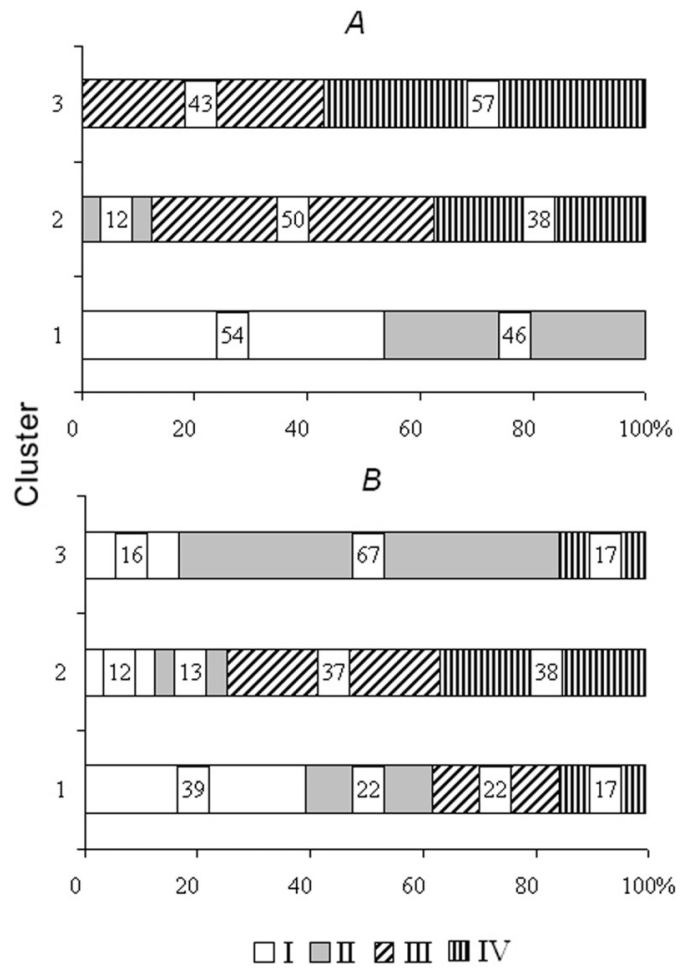

Fig. (3). Distribution of spruce (A) and pine (B) trees of different vitality categories (I - IV) among clusters. 


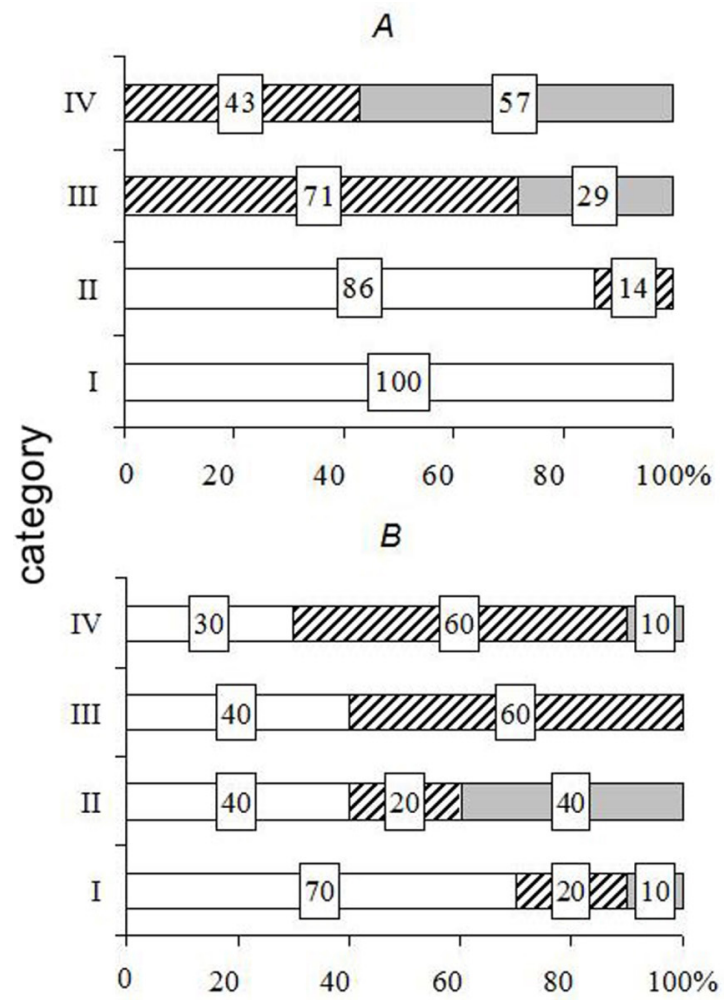

$\square 1 \boxminus 2 \square 3$

Fig. (4). Distribution of spruce (A) and pine (B) trees belonging to different clusters $(1-3)$ among different vitality categories (I - IV).

\section{DISCUSSION}

The daily patterns of $\Psi$ of shoots of spruce and pine trees of different vitality status are similar and they are corresponded well to $\Psi$ patterns of trees growing under reference conditions far away from active sources of industrial pollution $[21,22]$. It indicates that the basic biophysical mechanisms of water regulation in trees (stomata regulation of the leaves and, probably, also the structural adaptation) are kept even under strong industrial pollution [23].

The results of our study demonstrate that industrial pollution results in changes of tree architecture. Deterioration of tree vitality status is accompanied by decrease of lifespan of needles and reducing the sapwood area of both spruce and pine trees. Apparently, the reduction of leaf area of the trees due to loss of needles (especially in the lower parts of tree crowns) [23] leads to decrease of total crown transpiration, which, in turn, results in increase of $\Psi$ (decrease of water deficit) to avoid the consequences of embolism. As is well known [24-28] the water transport system of woody plants is well balanced and any decrease of evaporating surface may results in reduction of sapwood cross-section area. After restoration of tree structure, the previous cross-section xylem area and water supply rate are also recovered. It can be assumed that these alterations are adaptive and aimed to maintain $\Psi$ variation range. However, our study revealed balanced water transport system only in the trees of category I: they have the same number of living whorls and annual rings. At the same time for trees of category III and IV this balanced structure is damaged. This damage is, probably, a reason for increase of water deficit with deterioration of tree vitality status.

Direct effect of industrial pollution on plants is well known $[4,29]$. Thus, pollutants, deposited on a plant surface, destroy probably the photosynthetic apparatus of needles. Images provided by electron microscope show that outer stomata cavities of one-year-old needles of pine trees of the

Table 2. Shoot Water Potentials (MPa) of Pine and Spruce Trees of Different Vitality Categories Under Different Weather Conditions (Ff* - the Fisher's Criterion (Empirical), Fst - the Fisher's Criterion, $\mathbf{R}^{2}-$ Determination Coefficient, $\mathbf{p}-$ Statistical Significance)

\begin{tabular}{|c|c|c|c|c|c|c|c|c|c|c|c|c|}
\hline \multirow[t]{2}{*}{ Species } & \multirow[t]{2}{*}{ Date } & \multirow[t]{2}{*}{ Time } & \multirow[t]{2}{*}{$\mathbf{T},{ }^{\circ} \mathbf{C}$} & \multirow[t]{2}{*}{ Humidity, \% } & \multicolumn{4}{|c|}{ Tree Vitality Status } & \multicolumn{2}{|c|}{ Dispersion Analyses } & \multicolumn{2}{|c|}{$\begin{array}{c}\text { Regression } \\
\text { Analyses }\end{array}$} \\
\hline & & & & & I & II & III & IV & Ff*(Fst) & $\mathbf{p}$ & $\mathbf{R}^{2}, \%$ & $\mathbf{p}$ \\
\hline \multirow{7}{*}{ Spruce } & \multirow{7}{*}{10 July 93} & 0 & 7 & 73 & $-0.68 \pm 0.03$ & $-0.76 \pm 0.07$ & $-0.91 \pm 0.10$ & $-0.87 \pm 0.10$ & $F f^{*}(3.27)=11.24$ & $0.0001^{\mathrm{a}}$ & 50.3 & 0.0001 \\
\hline & & 6 & 7 & 85 & $-0.43 \pm 0.06$ & $-0.49 \pm 0.04$ & $-0.66 \pm 0.13$ & $-0.66 \pm 0.16$ & $\mathrm{Ff} *(3.22)=6.63$ & $0.0023^{\mathrm{a}}$ & 42.2 & 0.0018 \\
\hline & & 9 & 15 & 80 & $-1.03 \pm 0.05$ & $-1.10 \pm 0.06$ & $-1.30 \pm 0.10$ & $-1.21 \pm 0.12$ & $\mathrm{Ff}^{*}(3.25)=15.04$ & $0.0000^{\mathrm{a}}$ & 54.7 & 0.0000 \\
\hline & & 12 & 19 & 50 & $-1.18 \pm 0.13$ & $-1.29 \pm 0.07$ & $-1.31 \pm 0.15$ & $-1.32 \pm 0.08$ & $\mathrm{Ff}^{*}(3.28)=2.46$ & 0.0831 & - & - \\
\hline & & 16 & 25 & 40 & $-1.34 \pm 0.18$ & $-1.36 \pm 0.16$ & $-1.38 \pm 0.17$ & $-1.43 \pm 0.10$ & $\mathrm{Ff}^{*}(3.24)=0.42$ & 0.7432 & - & - \\
\hline & & 18 & 20 & 50 & $-1.18 \pm 0.13$ & $-1.18 \pm 0.10$ & $-1.23 \pm 0.07$ & $-1.19 \pm 0.07$ & $\mathrm{Ff}^{*}(3.22)=0.42$ & 0.7432 & - & - \\
\hline & & 24 & 10 & 75 & $-0.65 \pm 0.07$ & $-0.73 \pm 0.09$ & $-0.93 \pm 0.18$ & $-0.87 \pm 0.09$ & $F f^{*}(3.36)=13.77$ & $0.0000^{\mathrm{a}}$ & 49.2 & 0.0000 \\
\hline \multirow{2}{*}{ Pine } & \multirow{2}{*}{4 July 93} & 8 & 14 & 70 & $-0.87 \pm 0.08$ & $-1.02 \pm 0.05$ & $-1.01 \pm 0.03$ & $-1.08 \pm 0.10$ & $\mathrm{Ff}^{*}(3.28)=13.38$ & $0.0000^{\mathrm{a}}$ & 52.9 & 0.0000 \\
\hline & & 13 & 25 & 45 & $-1.01 \pm 0.06$ & $-1.04 \pm 0.08$ & $-1.01 \pm 0.06$ & $-1.00 \pm 0.06$ & $\mathrm{Ff}^{*}(3.13)=0.25$ & 0.8605 & - & - \\
\hline Spruce & \multirow{2}{*}{23 July 92} & \multirow[t]{2}{*}{16} & \multirow[t]{2}{*}{27} & \multirow[t]{2}{*}{45} & $-1.33 \pm 0.10$ & $-1.29 \pm 0.11$ & $-1.59 \pm 0.17$ & $-1.55 \pm 0.21$ & $\mathrm{Ff}^{*}(3.35)=10.01$ & $0.0001^{\mathrm{a}}$ & 62.1 & 0.0000 \\
\hline Pine & & & & & $-1.16 \pm 0.10$ & $-1.26 \pm 0.06$ & $-1.31 \pm 0.09$ & $-1.30 \pm 0.09$ & $F f^{*}(3.47)=7.95$ & $0.0002^{\mathrm{a}}$ & 33.7 & 0.0001 \\
\hline \multirow{2}{*}{$\begin{array}{l}\text { Spruce } \\
\text { Pine }\end{array}$} & \multirow{2}{*}{9 July 93} & \multirow[t]{2}{*}{13} & \multirow[t]{2}{*}{8} & \multirow[t]{2}{*}{70} & $-0.79 \pm 0.09$ & $-0.86 \pm 0.14$ & $-0.94 \pm 0.08$ & $-0.91 \pm 0.08$ & $F f^{*}(3.24)=3.08$ & 0.0466 & - & - \\
\hline & & & & & $-0.74 \pm 0.03$ & $-0.71 \pm 0.05$ & $-0.70 \pm 0.07$ & $-0.70 \pm 0.03$ & $\mathrm{Ff}^{*}(3.49)=0.48$ & 0.7047 & - & - \\
\hline
\end{tabular}


first category are clear of pollutants, and elongated epidermal cells are distinct well. Stomata of 1-year-old needles of IV category trees are strongly clogged, the cellular structure of the cover tissue is indiscernible, and the wax layer on the surface of 3-year-old needles is completely destroyed. Stomata there can be discerned only by the presence of large amounts of polymetal dust with high amount of $\mathrm{Ni}, \mathrm{Cu}, \mathrm{Fe}$, $\mathrm{Co}, \mathrm{Ti}$ and $\mathrm{Zn}$ on the surface [4].

Deposition of pollutants on soil surface results in changes of soil chemical composition and dying off of fine roots. Field data showed that the proportion of dead roots in the upper $10 \mathrm{~cm}$ layer of soil in our study area $(30 \mathrm{~km}$ from the combine) was $26 \%$, in the area closer to the combine (about $10 \mathrm{~km})$ - it increased up to $73 \%$ [29].

Thus, industrial pollution influences directly and indirectly all components of water conducting system of the trees. The influence is increased with decreasing the tree vitality status. Apparently it results in reduction of water transport conductivity in different parts of tree xylem. This, in turn, may generate a higher water deficit and a degradation of tree vitality status. Misbalance in the water transport system may be the reason of high variability of $\Psi$ for periods with rapid changes of weather conditions, as it was also observed in our study (Table 2).

Cluster analysis of experimental data showed that pine trees are characterized by a lower agreement level between categories determined by visual traits and $\Psi$, whereas for spruce such agreement is much higher. It is probably the reason of higher coefficients of determination in regression equations for spruce as compared with pine trees (Table 2).

Water deficit, assessed by $\Psi$ measurements under various weather conditions, increased non-linearly as the vitality status of pine and spruce trees deteriorated, probably due to the damage of water conducting system in trees. On the other hand, prolonged exposure to industrial pollution did not change the daily pattern of $\Psi$, and the range of its daily variation corresponded well to ranges obtained under reference conditions in forests with very low environmental pollution.

Comparisons of the responses of Siberian spruce and Scots pine trees to industrial pollution showed that a relationship between tree vitality statuses determined by visual traits and by a physiological criterion (tree water deficit) was more evident for spruce than for pine trees. It can be expected that at the same pollution level the time between pollution beginning and tree die-back may be shorter for spruce than for pine trees. Thus, spruce probably may be less resistant to pollution than pine trees. Therefore, changes of spruce forest conditions detected from remote sensing may be used for earlier diagnostic of industrial pollution.

\section{ACKNOWLEDGMENT}

The study was supported by grant of RFBR 09-04-00299-a.

\section{REFERENCES}

[1] Rigina O, Baklanov A, Hagnera O, Olsson H. Monitoring of forest damage in the Kola Peninsula, Northern Russia due to smelting industry. Sci Total Environ 1999; 199(3): 147-63.

[2] Getko NV. Plants in technogenous environment. Minsk: Navuka I Technika 1989. [in Russian]
[3] Kryuchkov VV, Makarova TD. Air-borne industrial impact on ecosystems in the Kola North. Apatity: USSR Acad Sci Kola Research Centre 1989. [in Russian]

[4] Kaibijainen LK, Hari P, Sofronova GI, Bolondinskiy VK. $\mathrm{CO}_{2}$ metabolism in vivo - plant status test under prolonged exposure to toxic pollutants. Russ J Plant Phys 1994; 41(5): 788-93. [in Russian]

[5] Sergeichik SA. Resistance of woody plants in technogenous environment. Minsk: Nauka I Technika 1994. [in Russian]

[6] Kozlov MV, Haukioja E, Bakhtiarov AV, Stroganov DN. Heavy metal in birch leaves around a nickel-copper smelter at Monchegorsk, Northwestern Russia. Environ Pollution 1995; 90: 291-9.

[7] Yarmishko VT. Scots Pine and Air Pollution in the European North. St. Petersburg: chemistry research institute, St. Petersburg University 1997. [in Russian].

[8] Lukina NV, Nikonov VV. Nutrient regime of North-taiga forests: natural and technogenic aspects. Apatity: Russian Acad Sci Kola Research Centre 1998. [in Russian]

[9] Suchareva TA, Lukina NV. Chemical composition and morphometric characteristics of Siberian spruce needles in the Kola Peninsula in the course of forest degradation succession. Lesovedenije 2004; 2: 36-43.

[10] Mikhailova TA, Berezhnaya NS, Ignatieva OV. Elemental composition of needles and morphophysiological parameters of Scots pine under industrial pollution. Irkutsk: IG SB RAS Publisher 2006.

[11] Alexeev VA. Forest ecosystems and atmospheric pollution. Leningrad: Nauka 1990. [in Russian]

[12] Poschenrieder C, Gunse B, Barcelo J. Influence of cadmium on water relations, stomatal resistance and abscisic acid content in expanding bean leaves. Plant Physiol 1989; 90: 1365-71.

[13] Terebova EN, Galibina NA, Sazonova TA, Talanova TYu. Individual variability of metabolic parameters of the assimilation system in Scots pine under industrial pollution. Lesovedenije. 2003; $1: 73-7$.

[14] Lyanguzova IV, Efimova MA. Relationship between plant vitality status and heavy metal content in them under industrial pollution. Ecological problems of plant communities. Sankt-Peterburg: BIN 2005; pp. 190-202.

[15] Larcher W. Ökologie der pflanzen. Stuttgart: Verlag Eugen Ulmer 1995.

[16] Hinekley TM, Lassoie JR, Running SW. Temporal and spatial variations in the water status of forest trees. Forest Sci Monogr 1978; 20: 186.

[17] Vasilieva NP, Gitarskiy ML, Karaban RT, Nazarov IM. Monitoring of pollution affected forest ecosystems in Russia. Lesovedenije. 2000; 1: 23-31. [in Russian].

[18] Scholander PF, Hammel HT, Hemmingsen EA, Bradstreet ED. Hydrostatic pressure and osmotic potential in leaves of mangroves and some other plants. Proc Natl Acad Sci USA 1964; 52: 119-25.

[19] Sazonova TA. Application of the pressure chamber in ecological studies // Biophysical Methods of Research in Woody Plant Ecophysiology. Leningrad: BIN 1979; 86-97. [in Russian].

[20] Hellkvist J, Richards G, Jarvis PG. Vertical gradients of water potential and tissue relations in Sitka spruce trees measured with the pressure chamber. J Appl Ecol 1974; 11: 637-67.

[21] Sazonova TA, Kolosova SV, Robonen EW. Rate of sap flow in Norway spruce // Monitoring of energy-mass exchange between atmosphere and forests ecosystems. Berichte des Forschungszentrums Waldoekosysteme 2002; B66: 83-7.

[22] Sazonova TA, Kaibijainen LK, Kolosova SV. Diagnosing water regime in Pinus sylvestris (Pinaceae). Russ J Bot 2005; 90(7): 1012-22. [in Russian].

[23] Kaibijainen LK. Ecophysiological studies of pine and pine stands. KarRC RAS Transactions. Petrozavodsk 2003; 5: 65-73. [in Russian].

[24] Waring R, Cholz H, Grier C, Plummer M. Evaluating stem conducting tissue as an estimator of leaf area in four woody angiosperms. Can J Bot 1977; 55: 1474-7.

[25] Rogers R, Hinckley TM. Foliar weight and area related to current sapwood area in oak. Forest Sci 1979; 25: 298-303.

[26] Hari P, Kaibijainen LK, Sazonova TA, Mäkelä A. Balance in the water transport system in Scots pine II. Active xylem. Lesovedenije 1985; 5: 74-7. [in Russian]. 
[27] Kaipiainen L, Hari P. Consistencies in the Structure of Scots Pine. In: Tigerstedt PMA, Puttonen P, Koski V, Eds. Crop physiology of forest trees. Helsinki: Helsinki University Press 1985; pp. 30-6.

[28] Kaibijainen LK, Hari P, Sazonova TA, Mäkelä A. Balance in the water transport system in Scots pine III. Conducting xylem area and needle mass. Lesovedenije 1986; 1: 31-7. [in Russian].
[29] Norin BN, Yarmishko VT. (eds.). Effect of industrial air-borne pollution on pine forests in the Kola Peninsula. Leningrad: BIN 1990. [in Russian].

Received: October 21, 2009

Revised: October 26, 2009

Accepted: October 26, 2009

(C) Sazonova and Olchev; Licensee Bentham Open.

This is an open access article licensed under the terms of the Creative Commons Attribution Non-Commercial License (http://creativecommons.org/licenses/by$\mathrm{nc} / 3.0 /$ ) which permits unrestricted, non-commercial use, distribution and reproduction in any medium, provided the work is properly cited. 